\title{
Assimilating Online Technologies into School Culture
}

\author{
Tamar Shamir-Inbal, Jacob Dayan, and Yael Kali \\ Technion - Israel Institute of Technology, Haifa, Israel \\ shamirt@gmail.com; jdayan@alumni.technion.ac.il; \\ yaelk@technion.ac.il
}

\begin{abstract}
The goal of this research was to design, implement, and evaluate a three-year Teacher Professional Development (TPD) model with a socio-constructivist approach, intended to support teachers to design and develop their own online activities and enable schools to assimilate online technologies into their school-culture.

The TPD was implemented in three schools with 45 teachers. Quantitative and qualitative analyses show that online activities developed by teachers toward the end of the intervention had a significantly higher pedagogical value than those developed at the beginning of the intervention. Additionally, the amount of action in all three of the schools' websites significantly increased throughout the intervention and continued to stay high one year afterwards. Four main teacher profiles emerged, showing how schools became less dependent on the external mentor and gradually learned to build on local resources and social capital to maintain the high quality and quantity of the online instruction.

Interpreting these findings using two frameworks - the school reform framework and the technology adoption life-cycle framework - we evaluate that the change processes in the schools were both substantial and sustainable. We conclude that, with proper TPD, teachers can play a key role as designers and developers of their own online activities.
\end{abstract}

Keywords: Socio-constructivist pedagogies, Teachers professional development (TPD), Assimilation of online technologies, Technology adoption life-cycle

\section{Introduction}

Educational systems around the world are required now, more than ever before, to adapt to the spirit of the time and to embrace technological innovation. Moreover, schools are required to prepare today's children and students - the citizens to be - for living in the information society. The

Material published as part of this publication, either on-line or in print, is copyrighted by the Informing Science Institute. Permission to make digital or paper copy of part or all of these works for personal or classroom use is granted without fee provided that the copies are not made or distributed for profit or commercial advantage AND that copies 1) bear this notice in full and 2) give the full citation on the first page. It is permissible to abstract these works so long as credit is given. To copy in all other cases or to republish or to post on a server or to redistribute to lists requires specific permission and payment of a fee. Contact Publisher@InformingScience.org to request redistribution permission. introduction of technological innovations into schools and the integration of online technologies in education is a challenging process that calls for change in teacher's pedagogical perceptions and instructional strategies (Fullan, 2006; Kumari, 1998; Salomon \& Ben-Zvi, 2006).

The current research seeks to facilitate this change process and enable success-

\section{Editor: Alex Koohang}

An earlier, shorter version of this paper was presented at the Chais conference 2009, in Raanana, Israel, and included in Y. Eshet-Alkalai, A. Caspi, S. Eden, N. Geri, \& Y. Yair (Eds.), Proceedings of the Chais conference on instructional technologies research 2009: Learning in the technological era. Raanana: The Open University of Israel. http://www.openu.ac.il/research center eng/conferences.html 
ful assimilation of online technologies into school culture. The basis of this research and its theoretical foundation lie in the socio-constructivist paradigm. The origins of this paradigm are in Piaget's constructivism, claiming that learning is an active process in which learners construct their own understanding and knowledge by making connections between new information and past experiences and knowledge (Piaget, 1972). The socio-constructivist epistemology extends Piaget's theory by emphasizing the socio-cultural aspects of the learning process and the important role of social interaction and cultural artifacts in constructing one's learning (Vygotsky, 1978).

Over the past three decades, numerous studies have shown that Information and Communication Technology (ICT) has a significant added value in the implementation of socio-constructivist pedagogies in education. Moreover, teachers can leverage on advanced technologies to successfully cope with didactical, organizational, and contextual matters by facilitating accessibility to information and using interactive and collaborative tools (Capper, 2003; Dori, Tal, \& Peled, 2002; Kali, Levin-Peled, \& Dori, 2009; Linn, Davis, \& Bell, 2004; Salomon \& Ben-Zvi, 2006). Knowledgeable use of such tools can enhance meaningful understanding of concepts and processes (Kali \& Linn, 2007; Koszalka, 2001; Linn et al., 2004; Roschelle, Pea, Hoadley, Gordin, \& Means, 2000). Yet, in spite of the growing use of ICT in schools, teachers tend to use technology for the implementation of traditional pedagogies; in most cases a teacher-centered transmissionist model is employed, rather than taking advantage of the technology to apply a learner-centered constructivist and socio-constructivist model. The result is that the most frequent use of online technologies in school is for browsing the Web, gathering information, and simple processing of this information (Fishman, Marx, Blumenfeld, Krajcik, \& Soloway, 2004; Herrington, Reeves, \& Oliver, 2005; Mioduser \& Nachmias, 2002; Roschelle et al., 2000). Only a small portion of the educational sites on the Web include activities that fulfill the potential of ICT to support complex educational activities that take advantage of the technology to facilitate learning in social and collaborative contexts (Mioduser \& Nachmias, 2002; Roschelle et al., 2000).

In our quest to reach an effective, sustained, and authentic reform, which fulfills the potential of ICT in education, we can evaluate the reform from two distinct, yet complimentary and sometime overlapping perspectives. One perspective is the change process itself. In this perspective we use the school-reform literature to examine the nature of the change and to interpret this change for the school as a whole, and for individual teachers (Cuban, 1993, 2001; Fuchs, 1995; Tyack \& Cuban, 1997). Another perspective is the Technology Adoption Life Cycle perspective. Here, we use well-known frameworks from the marketing arena to explore the degree to which the technology, and the way we envisioned teachers using it, was adopted by schools (Moore, 2002; Rogers, 1995). We also used these frameworks to better understand the processes schools went through in adopting the technology and its specific use in this study.

The goal of the current research was to design, build, implement, and evaluate a three-year socioconstructivist Teacher Professional Development (TPD) model, intended to support schools in assimilating online technologies into their school-culture. We refer to the term "assimilation of online technologies into school culture" as describing a situation in which a significant number of teachers are independent in maintaining and frequently updating their own class-websites and in building meaningful online activities for students in these websites, which are aligned with the curriculum and with the school's vision. To achieve this goal, we addressed the following questions at two levels of analysis: (a) the level of the school, and (b) the level of the teacher.

(a) The teacher level:

- How did the intervention with the TPD model affect the quality of online activities developed by teachers?

- What are typical processes that teachers undergo in assimilating online technologies? 
(b) The school level:

- How did the implementation of the TPD model affect the amount of action in the schools' class-websites?

- To what extent was the online action in the schools' class-websites sustained by teachers one year after the termination of the intervention with the TPD model?

\section{Theoretical Background}

\section{The Change Process and School Reform Perspective}

Schools in many parts of the world are required periodically to implement a new reform and to make significant changes in the way they work and operate. The pressure on schools to present an "innovative" and "adaptive" image often brings schools to make superficial changes and demonstrate change-related activities without real adoption of the reform rationale (Cuban, 2001; Rogers, 1995; Tyack \& Cuban, 1997). Fuchs (1995) offers a theoretical framework for the evaluation and classification of reforms in educational institutions (Table 1). In this research we use this three-level categorization to interpret the research findings and to evaluate the level of assimilation of the change induced by implementing our TPD model in schools.

Table 1: Assessing levels of change in educational organizations (Fuchs, 1995).

\begin{tabular}{|c|c|c|}
\hline $1^{\text {st }}$ degree change & $2^{\text {nd }}$ degree change & $3^{\text {rd }}$ degree change \\
\hline $\begin{array}{l}\text { Tangible changes in actions } \\
\text { and processes }\end{array}$ & $\begin{array}{l}\text { Rationale-based change ac- } \\
\text { tivities }\end{array}$ & Change in vision and essence \\
\hline $\begin{array}{l}\text { Progress or improvement in } \\
\text { an existing trajectory }\end{array}$ & $\begin{array}{l}\text { Search and development of } \\
\text { new trajectories }\end{array}$ & Implementing a new trajectory \\
\hline $\begin{array}{l}\text { Dependency on external re- } \\
\text { sources }\end{array}$ & $\begin{array}{l}\text { Slow trend of using internal } \\
\text { resources }\end{array}$ & $\begin{array}{l}\text { Autonomous execution and } \\
\text { use of internal resources }\end{array}$ \\
\hline $\begin{array}{l}\text { Sharp transition between ac- } \\
\text { tion and non-action }\end{array}$ & $\begin{array}{l}\text { Slow, careful, moderate activ- } \\
\text { ity }\end{array}$ & Change as a way of being \\
\hline Sporadic changes & $\begin{array}{l}\text { Staged and structured } \\
\text { changes }\end{array}$ & Holistic change \\
\hline $\begin{array}{l}\text { Change in one or few ele- } \\
\text { ments }\end{array}$ & $\begin{array}{l}\text { Change in one or few ele- } \\
\text { ments in conjunction with } \\
\text { cognitive rationale }\end{array}$ & $\begin{array}{l}\text { Multi-dimensional change in } \\
\text { all elements }\end{array}$ \\
\hline $\begin{array}{l}\text { Expectation for immediate } \\
\text { results }\end{array}$ & Milestone planning & Long-term planning \\
\hline $\begin{array}{l}\text { Involvement and interest by a } \\
\text { small group while opposition } \\
\text { groups arise }\end{array}$ & $\begin{array}{l}\text { More involvement, less oppo- } \\
\text { sition, growing interest }\end{array}$ & All parties are involved \\
\hline Quantitative change & $\begin{array}{l}\text { Beginning of qualitative } \\
\text { change }\end{array}$ & Qualitative change \\
\hline
\end{tabular}


For a change process to be substantial, it has to include the design of designated implementation activities for the application of the change in the classroom. The design must include monitoring and assessment processes that cover various stakeholders, such as principals, teachers, and the reform design team (Tyack \& Cuban, 1997). Successful implementation of a change is greatly influenced by both the individuals involved and the school's culture. Schools that support pedagogical innovation and team work are likely candidates for successful change implementation processes (Fishman et al., 2004; Furman-Shaharabani \& Tal, 2008). Studies show that in order to achieve sustainable reform, bottom-up and top-down processes should be combined. In this way the change is rooted on teachers' tacit knowledge, and teachers play a key role in establishing the change, while pedagogical support is provided by the reform design team, and the endorsement and financial support are provided by the authorities (Cuban, 1990; Fishman et al., 2004; Hargreaves \& Fullan, 1992).

\section{The Technology Adoption Life Cycle Perspective}

The technology adoption life cycle model, which comes from the marketing world, suggests that every new technological innovation is accepted by people at different rates and phases. Rogers (1995) and Moore (2002), who continued to develop this notion, defined five types of technology adopters: innovators, early adopters, early majority, late majority and laggards. The distribution of these types roughly follows standard deviations in a bell curve (Figure 1).

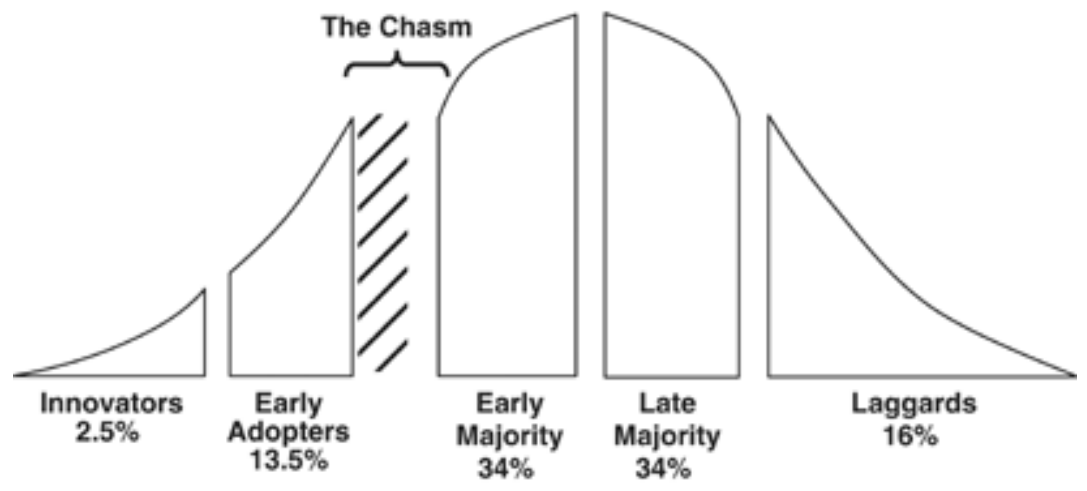

Figure 1: Technology Adoption Life Cycle (Rogers, 1995; Moore, 2002)

The innovators, who constitute a very small portion of the potential market, are eager to adopt innovations even if it means that they have to work hard to make these innovations work for them. Innovators pursue new technologies because technology is a central interest in their life, regardless of what function it is performing. The early adopters, a slightly larger percent of the market, understand and appreciate the benefits of a new technology and relate these potential benefits to their other concerns. Whenever they find a strong match, they are willing to base their buying decisions upon it. The early majority, who constitute approximately one third of the market, are driven by a strong sense of practicality (and are therefore referred to as Pragmatists). They want to see well-established references that the technology is stable before investing substantially. The late majority, who constitute another third of the market, share all the concerns of the early majority, plus one major additional one: they prefer to wait until the product has become an established standard and has significant support. Finally there are the laggards, who are resistant to any new technology and will buy the technology only if it's "well buried" inside another product.

The ultimate goal of marketers is to scale up a product to the majority of the potential market, yet many products fail in the start-up stage and many innovations do not pass the innovators or the early adopters segments and fail to reach the vast majority. In his "Crossing the chasm" theory, Moore (2002) shows that hidden chasms between "early adopters", "early majority" and "late 
majority" prevent from certain technologies to mature and reach the vast majority (Figure 1). A key factor in crossing the chasm and reaching the majority is Levitt's "whole product" marketing concept (in Moore, 2002). The whole product bridges the gap between the generic product and the ability to fulfill the promise to the end user. This is the gap between marketing promise, the actual product, and the expectation of the majority of users from the product.

Taking the risk of oversimplification, Moore's chasm theory, and the "whole product" marketing concept, can be illustrated by the market adoption of the portable MP3 music player. In a nutshell, a generic product evolves to become a "whole product" by passing three phases: the expected product, the augmented product, and the potential product. The expected product is the minimum configuration expected by the user. The generic product of portable music players surfaced in the early 90's and the MP3 format started to spread over the Internet. The product became the "expected product" in 1997-1998 when Winamp was launched, and companies like Rio and Diamond offered CD-based MP3 players. Moore suggests that the single most important difference between early adopters and the early majority is that the former are willing to piece together a whole product, whereas the later are not. At this stage, it was clearly an innovators and early adopters market - users had to piece together several components and to work quite hard to get MP3-CD to work. Taking portable music players to the next level - the early majority - required augmenting the product with the extensions required to maximize the chance of achieving user's objectives. In our example, this happened when flash memory technology was introduced to portable music players, reshaping the form factor and extending playing time. The product crossed the chasm between the early-majority to the late-majority with the introduction of Apple's iPod in 2001. According to Moore, the late-majority is buying a whole product that is a holistic representation of the solution, including additional software, system integration, training and support, installation, standards and procedures, and everything else that is required to achieve a compelling reason to buy and implement the technology. The generic portable music players of the early 90's is today an holistic solution with integrated music stores (i.e. iTunes), integrated into operating systems and software music players, standard sockets to connect to audio systems and remote controls, car audio, and more (Moore, 2002).

In this research we use the technology adoption life cycle perspective to illustrate how specific activities that we designed in the TPD model enabled schools to pass those "hidden chasms" to a stage in which almost all teachers in schools embraced the "whole solution" that we offered as we reached the third year of the intervention.

\section{Profiles of Technology-Adopter Teachers}

Studies regarding implementation of technology in education emphasize the relation between teacher personality and his or her willingness to use online educational technologies in the classroom. Research shows that teachers who are first to implement and use technology as part of their teaching practices are flexible risk-takers, with a lower requirement for structure and control. On the other side of this continuum are teachers with a more conservative approach, who prefer a steady environment, organized timetables, and firm structures. These teachers are less likely to adopt technology into their instruction (Fuller, Norby, Pearce, \& Strand, 2000). Novice teachers need to be comfortable with the new technology, properly trained to use it, and gain some experience with the tools before they are ready to embed it within their instruction and find ways apply it according to their pedagogical approaches (Kearsley \& Blomeyer, 2004).

A study by Dori, Tal, and Peled (2002) classifies teachers in four categories: (a) "the initiator and path-finder" is the enthusiastic, confident teacher, willing to implement online technologies whenever possible, (b) "the follower" is the conformist teacher, willing to apply online technologies at convenience, (c) "the avoider" that will use online technologies when he is forced to, and (d) "the antagonist" that will not use online technology in teaching under any circumstances. This 
classification seems to align with the classification in Rogers' technology adoption model (1995), with initiating teachers (type a) mapping to early adopters, followers (type b) to early majority, avoiders (type c) to late majority, and antagonists (type d), to laggards.

Becker and Ravitz (1999) profiled the technology leaders in schools as those teachers that follow the latest technological innovations, are willing to deal with technology glitches, and tend to experiment with new pedagogical initiatives. Teachers that are technology leaders can play a significant role as change agents in the assimilation of ICT into schools. These early adopters and technology leaders can become the key players in collaborating with external reform design teams and often gain a position of formal leaders within the school (Janson \& Janson, 2009). Careful profiling of teacher's characteristics, perceptions, and attitudes about the impact of ICT in education provides the foundation for the design of TPD programs that prepare teachers for ICT implementation (Dawes, 1999).

\section{Teacher Professional Development in the Context of Technology Usage}

Teaching in a technology-rich environment requires teachers to master new tools and pedagogical strategies and to integrate them into daily classroom activities. Two decades ago, when computers were not as common in schools as they are today, Shulman (1986) described the type of knowledge that teachers need to have as "Pedagogical Content Knowledge" (PCK). In accordance with the new requirements from teachers nowadays, Mishra and Koehler (2006) define a new type of knowledge, which they refer to as "Technological Pedagogical Knowledge" (TPK). This type of knowledge describes what teachers need to know to use technology in a way that would serve pedagogical considerations of the teacher. Therefore, it requires not only mastering the technology itself, but also making informed decisions, guided by a coherent pedagogical rationale regarding its use (Fishman et al., 2004; Green \& O'Brien, 2001). Research shows that in order for teachers to develop this type of knowledge and assimilate ICT in a meaningful and sustainable manner, TPD programs should build on local teacher leadership (Bowyer, Gerard, \& Marx, 2008). Involving leading teachers in decision-making regarding the nature of the change induced by the technology enhances teachers' TPK (Davis \& Varma, 2008; King \& Dunham, 2005) and fosters sustainability of the change process (Janson \& Janson, 2009). To enable such active involvement, it is important to provide teachers with a supportive climate in multiple levels: at the level of peers, the school level and the district level (Fullan, 2006; Furman-Shaharabani \& Tal, 2008; Guskey, 1998; Harris, 1994; Rogers, 1995). Salomon (2000) elaborates on this notion and suggests that in order for teachers to be willing to learn and use new tools, implement new educational methods, and cooperate with external change agents, they first need to acknowledge the need for change, be motivated to accepts the new ideas, and acquire positive attitudes related to the values associated with the change. Salomon suggests that implementation of new technologybased pedagogical ideas carried out by an external third party, without active involvement of the teachers, is short lived. He shows that as soon as the third party completes the implementation project, the ideas tend to fade out and the new technological-based tools are soon abandoned. The acquisition of TPK requires a system-wide approach and detailed design of TPD programs that are tailor-made to the specific needs of the school. The TPD literature describes three dimensions that need to be addressed simultaneously in order for an implementation program to be successful: the technology dimension, the policy/organizational dimension, and the pedagogical dimension (Fishman et al., 2004; Janson \& Janson, 2009).

\section{The technology dimension}

The technological perspective refers to the computer infrastructure in schools. It includes the quantity of computers, their maintenance and availability, accessibility, broadband Internet con- 
nectivity, and the technical support available at the school level. Implementing ICT requires that each of those parameters will be at a high level (Ravitz, 1998). Teachers must gain enough confidence and experience with the technological infrastructure before they address the challenge of using the technology with the relevant pedagogy for their educational methods (Capper, 2003).

Availability of software tools that complement the physical infrastructure is also a prerequisite. In recent years, online Learning Content Management Systems (LCMSs) have been developed. The availability of such systems in schools offer educators tools to develop their own online educational learning materials (Robbins, 2002; Ryann, 2001). The LCMSs ease of use bridges the gap between the technology-savvy teachers and the novice teachers, and enables all teachers to independently design and deploy online content (Shamir-Inbal \& Kali, 2009a)

\section{The policy/organizational dimension}

This dimension refers to the degree to which authorities at various levels (principals, administrators, and districts) provide support in teacher training programs, guide teachers in assimilation of change processes, encourage them to cooperate with external change agents, and motivate them to participate in the change process (Ellis \& Phelps, 2000). Fishman et al. (2004) suggest that effective assimilation of ICT requires teachers and principals to revisit the school's vision and reshape it to embrace innovative technologies into the school culture. This brainstorming process and the inclusion of all stakeholders in reshaping a school's vision to incorporate ICT is critical for the success of the assimilation process (Bowyer et al., 2008). Research shows that the principal's role is crucial in this process; principals who convey the message that ICT should serve an integral part of the school's practices and support teachers in doing so, both in a personal manner and an organizational manner, motivate teachers to take growing responsibilities related to ICT incorporation into their everyday practices (Peled, Kali, \& Dori, 2007).

\section{The pedagogical dimension}

For ICT technology to be meaningful and substantial for learning and instructional processes, and for teachers to acquire technological skills and harness technology for pedagogical use, the educational rationale of using the technology must be defined (Salomon, 2000). However, the educational rationale, as seen by designers of technology-based programs, does not always meet teachers' ideas about instruction that emerge from their practical experience and tacit knowledge. Sustained, long-term and systematic guidance, which includes pedagogical as well as technological aspects, can achieve the required conceptual change and enable effective adoption of technologies by teachers (Davis \& Varma, 2008; Fishman et al., 2004; Furman-Shaharabani \& Tal, 2008; Varma, Husic, \& Linn, 2008). One way to support such a change is to enable teachers to engage as learners with the same instructional approaches that the TPD seeks to promote. For example, when teachers are requested to use ICT to support collaborative learning, they can be asked to use similar technologies for collaboration, team work, and interactive communication as part of their TPD programs (Shamir-Inbal \& Kali, 2009a). In this manner the collaboration process can contribute to teachers' learning of the TPD contents, as well as to their adoption of the instructional strategies (Cordingley, Bell, Rundell, \& Evans, 2003; Dori et al., 2002).

\section{Research Context}

The current research was conducted in conjunction with a national effort to assimilate ICT into schools in northern Israel and to encourage teachers to create, manage, and maintain their own class-websites. Schools in this project were provided with a simple LCMS, designed specifically to support class management. This system enables each teacher, even with little experience with technology, to build a simple class website, with a given format including the following items: (a) instructions for online activities and tasks, (b) forums, (c) online surveys, and (d) links to relevant 
websites. These items are organized in categories defined by the teacher (such as "our survey" or "task of the week") and are arranged in the webpage either as main items that are highlighted at the center or as regular items that appear at the sides (see Figure 2). In order to support the assimilation process of using the system, the Israeli ministry of education allocated mentors that would train teachers to use it. It is important to note that the intervention with the TPD model described in the current research was not part of the national project. Rather, we developed it independently to study how we can augment the impact of the national project. The national project allocated resources for providing individual mentoring to teachers. Our rationale was that, with the same resources, a greater impact would be reached with a more holistic TPD approach. Thus, the design of the intervention took advantage of resources provided by the ministry of education: (a) 6 hours of bi-weekly individual guidance for teachers per school, and (b) resources that were designated to one whole-school and one district teacher workshops. In addition, the schools that participated in the study allocated two hours per week for leading-teachers to provide support to their peers.

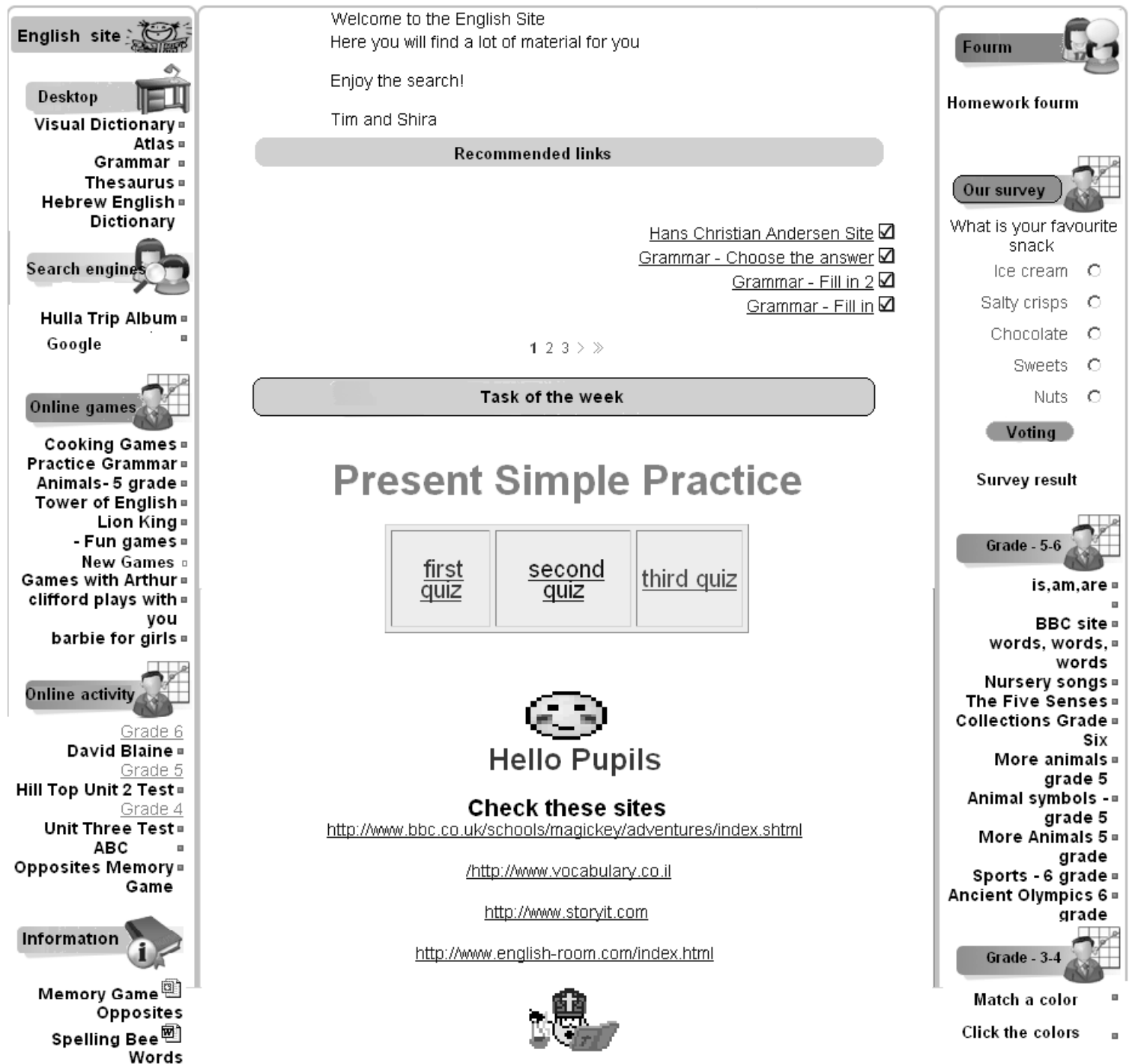

Figure 2: Example of a class website constructed by an English teacher 


\section{Participants}

The intervention was conducted as a three-year TPD program and took part in three elementary schools between the years 2005 to 2008. School A had 22 teachers in the staff and about 350 students, school B had 21 teachers and about 300 students, and school C, which was smaller, had 12 teachers and about 150 students. The number of teachers who participated in the TPD changed during these years and between the schools, as we describe in the findings. Altogether, 45 teachers participated in the TPD. The mentor for the TPD program was the first author of this paper.

In addition, at the same time that the mentor implemented the TPD program in the three schools described above, she also participated as a mentor in an additional school as part of the national effort to assimilate ICT into schools in northern Israel. This fourth school was very similar to schools A and B in terms of size and socio-economic background, but we did not implement our TPD model in this school. The mentoring hours were used only for individual guidance of the teachers, without all the activities we describe below that the TPD model included. In this manner we were able to use this fourth school as a reference for examining our interpretations regarding the effect of the TPD model on schools A, B, and C.

\section{The TPD model}

The preliminary design of the TPD model developed in this study was based on the literature review, however, the model continued to evolve and widen throughout the three years of the intervention according to needs that emerged from the field. Additionally, a pilot study was conducted to determine the preliminary conditions required for a productive intervention in the context of the specific study (Shamir-Inbal \& Kali, 2007). The conditions that were found were: (a) willingness of the principal to take an active role in the process, (b) willingness of the teachers to take part in the TPD even though they knew this would require time and effort, (c) basic skills of teachers in using computers, and (d) availability of a simple-to-use LCMS in the school.

An important principle in our design considerations for developing the TPD model was that it would not require extra funding, but rather, would build on local resources found in the schools. We sought ways to maximize these resources in a way that would enable the growth of local leadership and would enable meaningful and sustainable assimilation of ICT use.

The TPD model was designed to combine different types of factors that have been shown, each dimension individually, to promote assimilation of technology in schools. The combination of the factors enabled us to examine the effect of the holistic approach on teachers' practices and on the assimilation of technology into the schools' cultures. With that rationale in mind, a threedimensional model illustrated as a "Rubik's Cube" (Figure 3) was designed, including the following dimensions: (a) The locality dimension refers to the importance of coordinating activities at the levels of the individual teacher, the school, and the district (Fishman et al., 2004); (b) The type of support dimension refers to supporting teachers with pedagogical, technological and organizational issues; (c) The cognitive apprenticeship stage dimension refers to the three main stages that comprise the cognitive apprenticeship model of instruction, namely modeling, coaching and fading away. These stages were defined by Collins, Brown and Newman (1989) as steps that can help novices gain knowledge from an expert. We borrowed this approach to contribute to the sustainability of the TPD model. In our case, the teachers were considered as novices in using technology as part of their teaching, and the mentor served as the expert.

For each one of the 27 small "cubes" comprising our three-dimensional TPD model, we designed activities that are described in Table 2. These activities address specific requirements of the schools we worked with, but they also serve as an example illustrating how each of the "cubes"-the intersections of the factors in each dimension -- can be employed. 


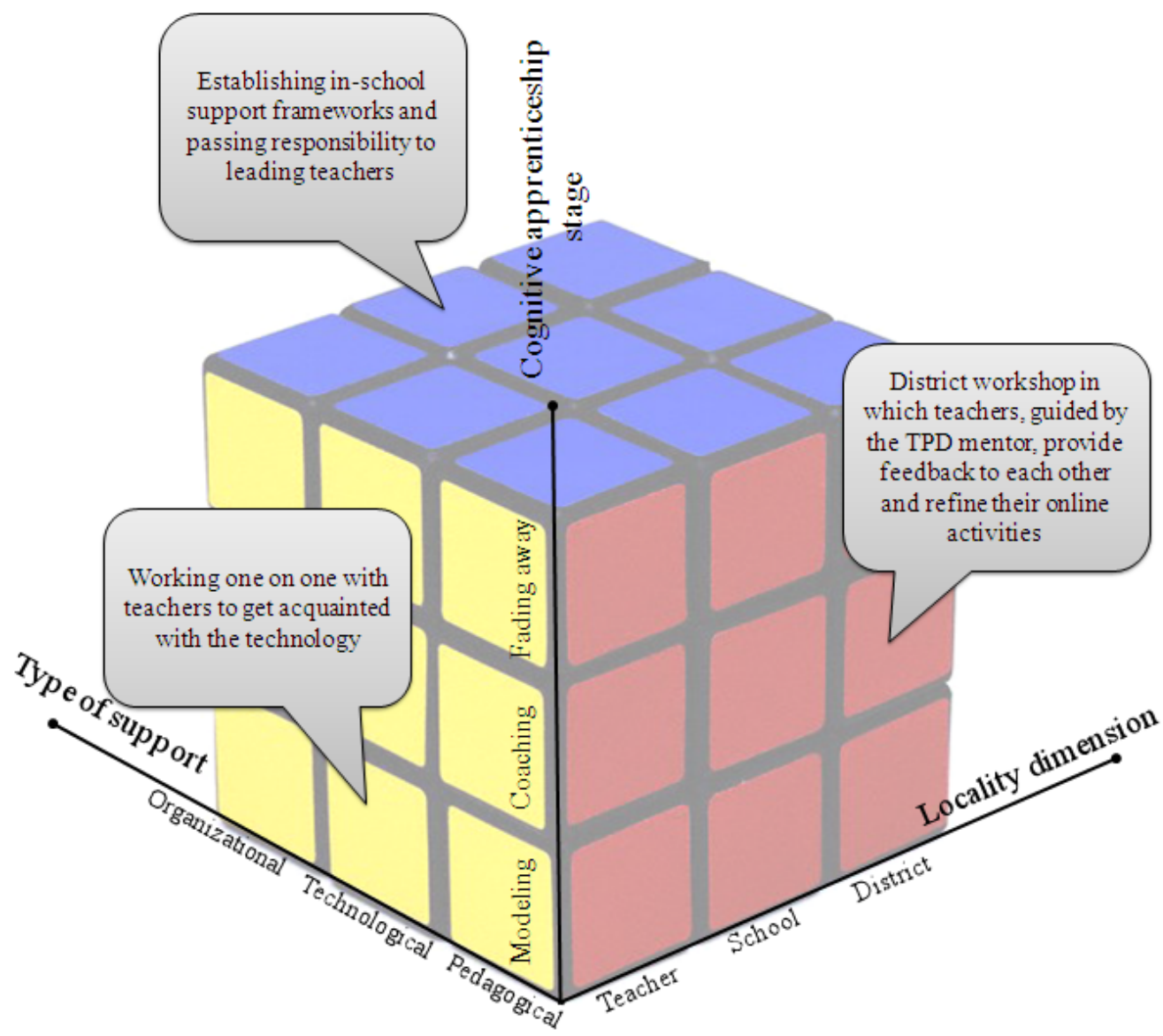

Figure 3: The three-dimensional teacher professional development model with 3 example activities

Table 2: The TPD model: Example activities in each "cube" of the three-dimensional model

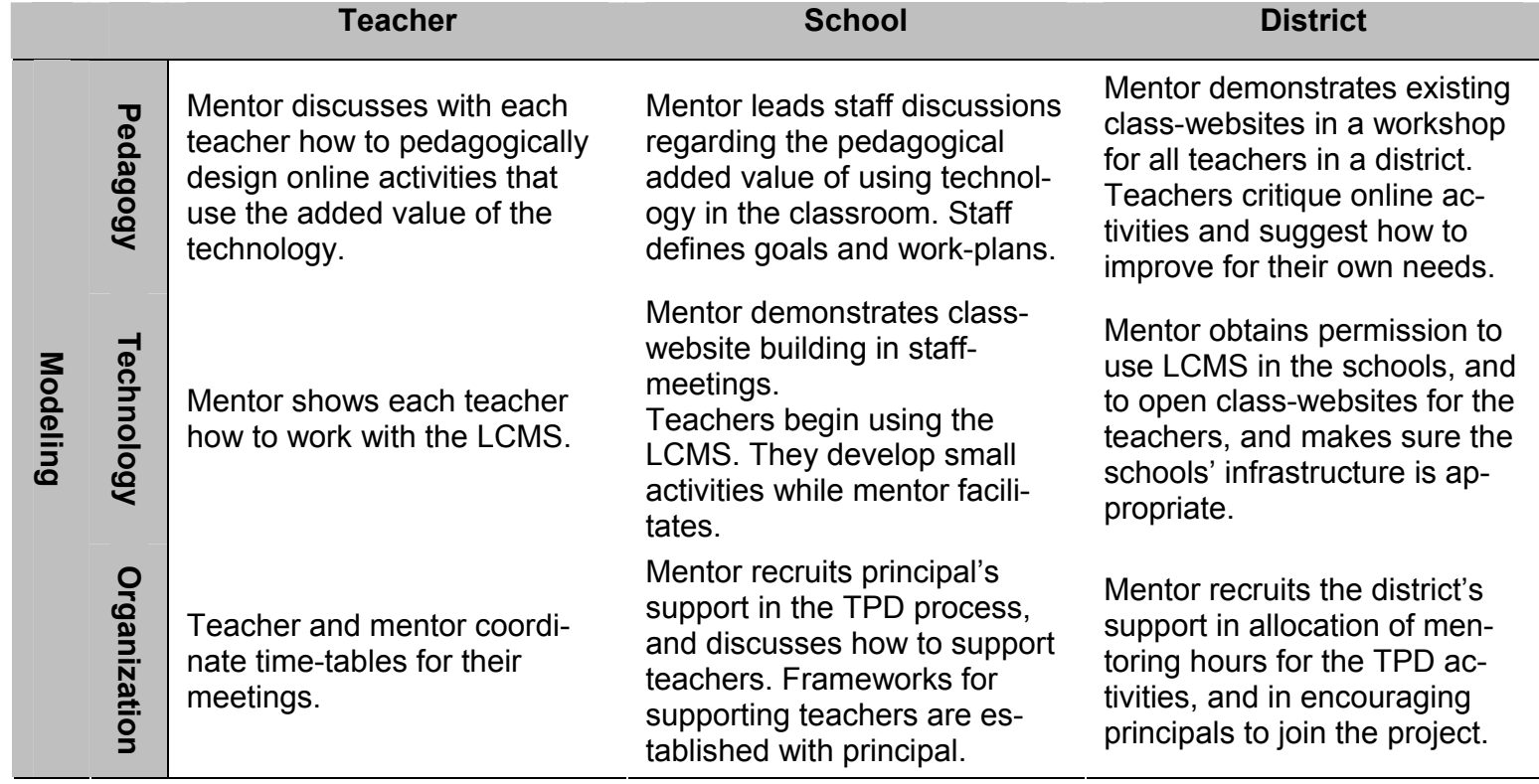




\begin{tabular}{|c|c|c|c|c|}
\hline & & Teacher & School & District \\
\hline \multirow{3}{*}{ 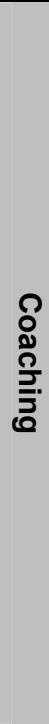 } & 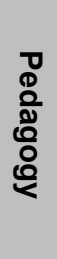 & $\begin{array}{l}\text { Teachers design their own in- } \\
\text { depth online activities with } \\
\text { one-on-one assistance from } \\
\text { the mentor, and sometime } \\
\text { from leading teachers }\end{array}$ & $\begin{array}{l}\text { Teachers participate in staff } \\
\text { meetings led by mentor, in } \\
\text { which they provide feedback } \\
\text { and critique each others' } \\
\text { online activities. Mentor intro- } \\
\text { duces the AOA rubric to sup- } \\
\text { port the processes. }\end{array}$ & $\begin{array}{l}\text { Teachers from the whole dis- } \\
\text { trict present their online activi- } \\
\text { ties to each other, provide } \\
\text { feedback and critique each } \\
\text { others' work using the AOA } \\
\text { rubric in a workshop led by } \\
\text { the mentor. }\end{array}$ \\
\hline & 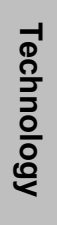 & $\begin{array}{l}\text { Mentor encourages teachers } \\
\text { to become more independent } \\
\text { in using the LCMS. }\end{array}$ & $\begin{array}{l}\text { As teachers become more } \\
\text { independent in using the } \\
\text { technology, leading teachers } \\
\text { are able to provide most of the } \\
\text { technological assistance in } \\
\text { using the LCMS. }\end{array}$ & $\begin{array}{l}\text { At the district level workshop, } \\
\text { teachers are presented with } \\
\text { online support systems that } \\
\text { can help them become more } \\
\text { independent solving techno- } \\
\text { logical problems. }\end{array}$ \\
\hline & 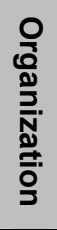 & $\begin{array}{l}\text { Mentor couples teachers who } \\
\text { are identified as leading } \\
\text { teachers with other teacher } \\
\text { who need more assistance. }\end{array}$ & $\begin{array}{l}\text { Time allocation gradually } \\
\text { shifts to more staff-meetings } \\
\text { on the expense of one-on-one } \\
\text { meetings with teachers. Lead- } \\
\text { ing teachers are identified to } \\
\text { support their peers. }\end{array}$ & $\begin{array}{l}\text { Schools present their class- } \\
\text { websites to district supervi- } \\
\text { sors and receive endearment } \\
\text { and financial incentives to } \\
\text { continue their work. }\end{array}$ \\
\hline \multirow{3}{*}{ 茕 } & 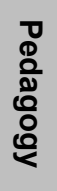 & $\begin{array}{l}\text { One-on-one support from } \\
\text { mentor is not required any- } \\
\text { more due to leading teachers' } \\
\text { support and to a higher } \\
\text { autonomy of the teachers. }\end{array}$ & $\begin{array}{l}\text { Teachers couple with each } \\
\text { other to collaboratively work } \\
\text { on their online activities. }\end{array}$ & $\begin{array}{l}\text { Schools continue to meet with } \\
\text { other schools in their district. } \\
\text { More responsibility is passed } \\
\text { to leading teachers in these } \\
\text { meetings. }\end{array}$ \\
\hline & $\frac{\substack{1 \\
\frac{0}{3}}}{\stackrel{0}{\circ}}$ & $\begin{array}{l}\text { Mentor provides technical } \\
\text { assistance to individual teach- } \\
\text { ers only online. Leading } \\
\text { teachers provide most of the } \\
\text { assistance. }\end{array}$ & $\begin{array}{l}\text { Leading teachers provide the } \\
\text { technological support. }\end{array}$ & $\begin{array}{l}\text { External online support sys- } \\
\text { tems and internal human- } \\
\text { capacity are sufficient at this } \\
\text { stage for schools to solve } \\
\text { technological problems. }\end{array}$ \\
\hline & 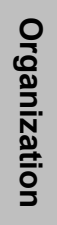 & $\begin{array}{l}\text { Organizational support is pro- } \\
\text { vided to teachers by school } \\
\text { staff. Mentor's assistance is } \\
\text { not required. }\end{array}$ & $\begin{array}{l}\text { Establishing in-school support } \\
\text { frameworks and passing re- } \\
\text { sponsibilities to leading } \\
\text { teachers. Mentor participates } \\
\text { in staff meetings but retreats } \\
\text { from a leading position. }\end{array}$ & $\begin{array}{l}\text { Reduction of mentoring hours } \\
\text { from the district. }\end{array}$ \\
\hline
\end{tabular}

\section{Methods}

In this section we describe the tools and data sources we used for collecting and analyzing data regarding the processes that occurred in the three schools over the three years of the intervention with the TPD model. Table 3 illustrates the tools and data sources used to answer each of the research questions. 
Table 3: Tools and data sources for each research question

\section{Research questions}

\begin{tabular}{|c|c|c|c|c|c|c|}
\hline $\begin{array}{l}\text { How did the intervention with the TPD model } \\
\text { affect the quality of online activities developed } \\
\text { by teachers? }\end{array}$ & $\checkmark$ & & $\checkmark$ & $\checkmark$ & & $\checkmark$ \\
\hline $\begin{array}{l}\text { What are typical processes that teachers un- } \\
\text { dergo in assimilating online technologies? }\end{array}$ & $\checkmark$ & $\checkmark$ & $\checkmark$ & $\checkmark$ & $\checkmark$ & $\checkmark$ \\
\hline $\begin{array}{l}\text { How did the implementation of the TPD model } \\
\text { affect the amount of action in the schools' class- } \\
\text { websites? }\end{array}$ & & $\checkmark$ & & & & \\
\hline $\begin{array}{l}\text { To what extent was the online action in the } \\
\text { schools' class-websites sustained by teachers } \\
\text { one year after the termination of the intervention } \\
\text { with the TPD model? }\end{array}$ & & $\checkmark$ & & & & \\
\hline
\end{tabular}

\section{Analyzing the Quality of Teacher-Designed Online Activities}

The activities designed and developed by the teachers were the main resource for studying the professional development of the teachers throughout the study. The activities were analyzed using the Analyzing Online Activities (AOA) rubric, which enabled us to quantitatively assess the quality of the online activities developed by teachers using a socio-constructivist lens (Shamir-Inbal $\&$ Kali, 2009b). The AOA rubric (Table 4) consists of six constructs, each one defined in three performance levels: low, intermediate and high. It is important to note that the AOA rubric was used not only as a research tool to assess the degree to which teachers' adopted socioconstructivist pedagogies in the online activities they developed, it also served as an instructional aid for the teachers to develop their activities. For instance, during district workshops, teachers were reviewed each other's online activities using the AOA rubric (see activities at the Coaching/Pedagogy/District levels in Table 2).

To asses to what extent the three-year intervention affected the quality of online activities developed by teachers, 25 activities that teachers developed at the beginning and 25 additional activities that they developed toward the end of the intervention were analyzed. The activities developed in these two time-frames were compared using Wilcoxon's rank sum test (Non-parametric procedures were taken due to the ordinal scale of the AOA). 
Table 4 - Analyzing Online Activities (AOA) rubric (Shamir-Inbal, \& Kali, 2009)

\begin{tabular}{|c|c|c|c|}
\hline Dimension & High Level (3) & Intermediate Level (2) & Low Level (1) \\
\hline $\begin{array}{l}\text { Added Value } \\
\text { of the Tech- } \\
\text { nology }\end{array}$ & $\begin{array}{l}\text { Technology is essential for } \\
\text { the activity. Students are } \\
\text { referred to a variety of rich, } \\
\text { current websites that include } \\
\text { visualizations, models, or } \\
\text { other means that can assist } \\
\text { in understanding the con- } \\
\text { tents. }\end{array}$ & $\begin{array}{l}\text { Technology enriches the } \\
\text { activity but is not essential to } \\
\text { it. Students are referred to } \\
\text { few websites that provide } \\
\text { additional information about } \\
\text { the issues discussed but are } \\
\text { not required to complete the } \\
\text { tasks. }\end{array}$ & $\begin{array}{l}\text { Use of technology is techni- } \\
\text { cal and does not affect the } \\
\text { essence of learning. Stu- } \\
\text { dents download traditional } \\
\text { worksheets, fill them out and } \\
\text { return them to the forum or } \\
\text { directly to the teacher. }\end{array}$ \\
\hline $\begin{array}{l}\text { Required } \\
\text { Level of } \\
\text { Thinking }\end{array}$ & $\begin{array}{l}\text { The activity encourages } \\
\text { higher order thinking: (pos- } \\
\text { ing questions, taking a } \\
\text { stand, making conclusions) } \\
\text { and encourages creativity, } \\
\text { responsibility and knowledge } \\
\text { integration. (Levels 3-6 - } \\
\text { Bloom, 1956) }\end{array}$ & $\begin{array}{l}\text { The activity requires the } \\
\text { learner to give examples, } \\
\text { descriptions, summaries or } \\
\text { general explanations of in- } \\
\text { formation gathered from the } \\
\text { internet. (Level } 2 \text { - Bloom, } \\
\text { 1956) }\end{array}$ & $\begin{array}{l}\text { Memorization of knowledge. } \\
\text { Focus on standard questions } \\
\text { and answers. Oriented to- } \\
\text { wards simple information } \\
\text { gathering assignments. } \\
\text { (Level } 1 \text { - Bloom, 1956) }\end{array}$ \\
\hline $\begin{array}{c}\text { Peer } \\
\text { Learning }\end{array}$ & $\begin{array}{l}\text { Online components are used } \\
\text { to support collaborative } \\
\text { learning as an essential part } \\
\text { of the activity. Learners } \\
\text { serve as information sources } \\
\text { for their peers. }\end{array}$ & $\begin{array}{l}\text { Scaffolds explicitly require } \\
\text { students to work in pairs or } \\
\text { groups, but there is no tech- } \\
\text { nological support for interac- } \\
\text { tion between fellow students } \\
\text { or between the groups. }\end{array}$ & $\begin{array}{l}\text { There is no reference to } \\
\text { collaborative learning. } \\
\text { Learners are sometimes } \\
\text { prevented from cooperating } \\
\text { with one another. Projects } \\
\text { are occasionally uploaded to } \\
\text { the forum, but only for re- } \\
\text { view by the teacher. }\end{array}$ \\
\hline $\begin{array}{r}\text { Ma } \\
\text { Con } \\
\text { Acce }\end{array}$ & $\begin{array}{l}\text { The activity connects to the } \\
\text { learner's cultural world, pre- } \\
\text { vious knowledge and ex- } \\
\text { perience. This is done by } \\
\text { choice of contents, nature of } \\
\text { problems and social context. } \\
\text { (Linn et al., 2004) }\end{array}$ & $\begin{array}{l}\text { An attempt is made to relate } \\
\text { the activity to the learner's } \\
\text { world, but the connection is } \\
\text { artificial or not meaningful. }\end{array}$ & $\begin{array}{l}\text { There is no attempt to relate } \\
\text { and make the contents ac- } \\
\text { cessible. Emphasis is on } \\
\text { content that the learner must } \\
\text { know or remember. }\end{array}$ \\
\hline $\begin{array}{l}\text { Scaffolding } \\
\text { for Rich } \\
\text { Artifacts }\end{array}$ & $\begin{array}{l}\text { Structured and scaffolded } \\
\text { assignments, that help } \\
\text { learners construct an arti- } \\
\text { fact, and enable the teacher } \\
\text { to serve as a facilitator. Arti- } \\
\text { fact is diverse, creative and } \\
\text { promotes personal capabili- } \\
\text { ties and self-expression. } \\
\text { (Reeves \& Reeves, 1997) }\end{array}$ & $\begin{array}{l}\text { Scaffolds enable a product } \\
\text { with a certain degree of } \\
\text { openness and personal ex- } \\
\text { pression, but are too general } \\
\text { to support a complex task. } \\
\text { For instance, "Write a story } \\
\text { about...", "What I would do } \\
\text { if...", "My opinion on...". }\end{array}$ & $\begin{array}{l}\text { Scaffolds guide towards a } \\
\text { uniform, closed artifact de- } \\
\text { fined by the teacher. No } \\
\text { creativity is required to pro- } \\
\text { duce the artifact. Such } \\
\text { activities include: standard } \\
\text { questions and answers, } \\
\text { sorting of data in a table, etc. }\end{array}$ \\
\hline $\begin{array}{l}\text { Embedded } \\
\text { Assessmen }\end{array}$ & $\begin{array}{l}\text { Assessment is performed by } \\
\text { the teacher or by fellow stu- } \\
\text { dents according to clear and } \\
\text { known criteria. Formative } \\
\text { assessment is embedded in } \\
\text { the learning process and } \\
\text { enhances it (Dori, 2003). }\end{array}$ & $\begin{array}{l}\text { There is reference to the } \\
\text { assessment of artifacts, but } \\
\text { no clear criteria are pre- } \\
\text { sented. Artifacts are some- } \\
\text { times presented on the web- } \\
\text { site or in class, but without } \\
\text { prompts for further learning } \\
\text { from these artifacts. }\end{array}$ & $\begin{array}{l}\text { There is no reference to the } \\
\text { way in which the learner is } \\
\text { assessed. Assessment is } \\
\text { summative. Products are } \\
\text { sent to the teacher to be } \\
\text { checked and graded. }\end{array}$ \\
\hline
\end{tabular}

We would like to note that during the intervention period, teachers designed many activities; in some (which we call in-depth activities), they invested much thought and time in designing, and in others (simple activities) they invested only little time and effort. In-depth activities were usually taught in several class-periods and were regarded by teachers as more meaningful to them than the simple activities that were smaller. For example, one in-depth activity, designed for sixth-grade students, was named "Historical tales told by stamps". The activity starts with presenting students with links to a wide variety of websites that show stamps that illustrate national 
historical events (Added Value of Technology $=3$ ). Students were asked to choose one stamp representing an historical event that interested them and that they would like to explore. The relation to the students' cultural world and former knowledge was made by asking students to present, in a forum, their argument for choosing their stamp and describe what they would like to learn about the historical event (Making Contents Accessible =3). In the next stage students were asked to explain how events described by their peers relate to the event they focused on (Required Level of Thinking = 3; Collaborative Learning = 3). Students were then asked to design a stamp that tells a historical story and present it in an off-line class meeting (Scaffolding ${ }^{1}$ for Rich Artifacts $=3$ ). Finally, students were required to critique another group's presentation and write what they have learned from it (Embedded Assessment $=2$ ). The 50 activities chosen for the analysis using the AOA rubric were the first and last in-depth activities that teachers, or teams of teachers, designed (note that not all teachers had two in-depth activities, but all those who did were included in the analysis).

Since the mentor was sometimes involved in helping teachers design and develop their online activities, especially at the beginning stages of the intervention, we had to evaluate the extent to which a teacher was autonomous in the development process, in order to take this into account in the assessment of the activities. Thus, we analyzed the activities using an index, which combines the pedagogical quality dimensions of the AOA rubric, with another rubric that evaluates the teacher autonomy in developing the activity (Table 5), as documented in the researcher's journal.

Table 5: The degree of teacher autonomy in designing online activities rubric

\section{Degree of teacher autonomy in designing online activities}

5 Full autonomy - mentor not involved

$4 \quad$ High independence - mentor only provides feedback

3 Intermediate independence - mentor provides technological backing and feedback

2 Low independence - mentor provides technological and pedagogical support

Full dependence - mentor "holds the teacher's hand" and provides much of the ideas.

The combined index enabled us to define a comparable value, from 0.3 to 1 , for assessing the activities designed by teachers, taking into account both the pedagogical quality of the activity (a scale of 1 to 3 in the AOA rubric) and the teachers' autonomy (a scale of 1 to 5). We define this index as follows:

$$
\text { Combined Index }=\frac{1}{2} x \frac{\text { Qualty }}{3}+\frac{1}{2} x \frac{\text { Autonomy }}{5}
$$

\section{Analyzing the Frequency of Updates to Class-Websites at a School Level}

The amount of action in the class-websites, which hosted the activities designed by the teachers, was an important resource for evaluating the assimilation of technology into the school's culture. We assessed the frequency of teachers' updates to the class-websites in five levels: (1) Informa-

\footnotetext{
${ }^{1}$ Scaffolding is an instructional strategy that involves supporting novice learners by limiting the complexities of the context and gradually removing those limits as learners gain the knowledge, skills, and confidence to cope with the full complexity of the context (Young, 1993).
} 
tional websites: sites that were developed as a one-time effort to provide information to students and were not maintained or updated at all by teachers. (2) Low frequency: sites that were updated by teachers two or three times a year. (3) Intermediate frequency: updated every two or three months. (4) High frequency: updated once every month or two. (5) High frequency: updated regularly.

It is important to note that for the assessment of the frequency of updates to class-websites, we referred only to meaningful updates such as the development of new in-depth or small activities. We did not count administrative messages as updates. We also want to note that this research focuses on teachers' actions and did not look at the frequency of students' activity in the classwebsites. Based on research showing a correlation between teacher-student activity in online websites (Mioduser \& Nachmias, 2002), we assumed that the frequency of teacher updates represents the total frequency of the usage of the class-websites. To assess the frequency of updates at a school level, we defined an index that calculates the average frequency of updates of all the teachers who had active class-websites in a school (these teachers were named "technology adopters"), in relation to their portion from all the teachers in the school. This index was defined as follows:

$\begin{gathered}\text { Frequency of updates } \\ \text { at a school level }\end{gathered}=\frac{\begin{array}{c}\text { Number of technology } \\ \text { adopters in the school }\end{array}}{\begin{array}{c}\text { Total number of teach- } \\ \text { ers in the school }\end{array}} \times \begin{gathered}\text { Average frequency of updates } \\ \text { of the technology adopters }\end{gathered}$

Data collection regarding the frequency of updates to class-websites began from the end of the first year of the intervention and was monitored once every two months until one school year after the end of the intervention.

\section{Calculating the Percentage of Teacher-Turnover in the TPD Program}

As described above, the amount of action in each of the schools' class-websites, or the frequency of updates, served as an important method to evaluate to what extent the technology was assimilated into the schools' cultures. However, teachers have many responsibilities in their schools besides assimilation of technology, and not all teachers chose to participate in the TPD model throughout the intervention. Thus, the number of teachers who participated in the TPD program changed considerably during the three years of the intervention. To get a better sense of the numbers we found for the frequency of updates at a school level, we also calculated the percentage of teacher-turnover in the TPD program as follows:

$$
\begin{gathered}
\text { Percentage of } \\
\text { teacher-turnover }
\end{gathered}=\frac{\text { Newcomers }+ \text { Dropouts }}{\text { Newcomers }+ \text { Dropouts }+ \text { Continuers }+ \text { Comebacks }}
$$

\section{Defining Typical Teacher Profiles}

To better understand the variety of roles and activities taken by teachers in schools that assimilate technology into their school cultures, and to characterize typical teacher profiles, we used the interview protocols, the teachers' reflection essays, and our researcher journal. To analyze the data 
we used Chi's framework for quantifying qualitative data (Chi, 1997). First, we created protocols for each teacher, including all the qualitative information we gathered about that teacher. Then, we segmented the protocols into episodes and found categories and sub-categories that emerged from that analysis for describing similar types of episodes. We also used the quantitative information about each teacher (quality of online activities as derived from the AOA rubric, and frequency of updates to the class website) to strengthen the qualitative analysis. The next step was to code the episodes using the categorization scheme developed at the former stage (Defining the categorization scheme and using it to characterize each of the teachers required several iterations of refinement until a stable categorization scheme was established, which resulted in a $95 \%$ agreement between the three authors). Finally, a framework of four main teacher profiles was defined, each including two or three sub-categories, as we describe in the results section below.

\section{Findings}

In this section we first describe findings related to the level of the teacher: (a) the pedagogical quality of teacher-designed online activities, (b) typical teacher profiles. Then we continue to describe the findings at the level of the school: (c) teacher-turnover in the TPD program, (d) frequency of updating class-websites at a school level.

\section{The Pedagogical Quality of Teacher-Designed Online Activities}

Figure 4 represents the average quality of online activities developed by teachers, as derived via analysis with the AOA rubric, at two points: (a) the beginning of the intervention (the first indepth activities developed by the 25 teachers), and (b) the end of the intervention (the final indepth activity they developed).

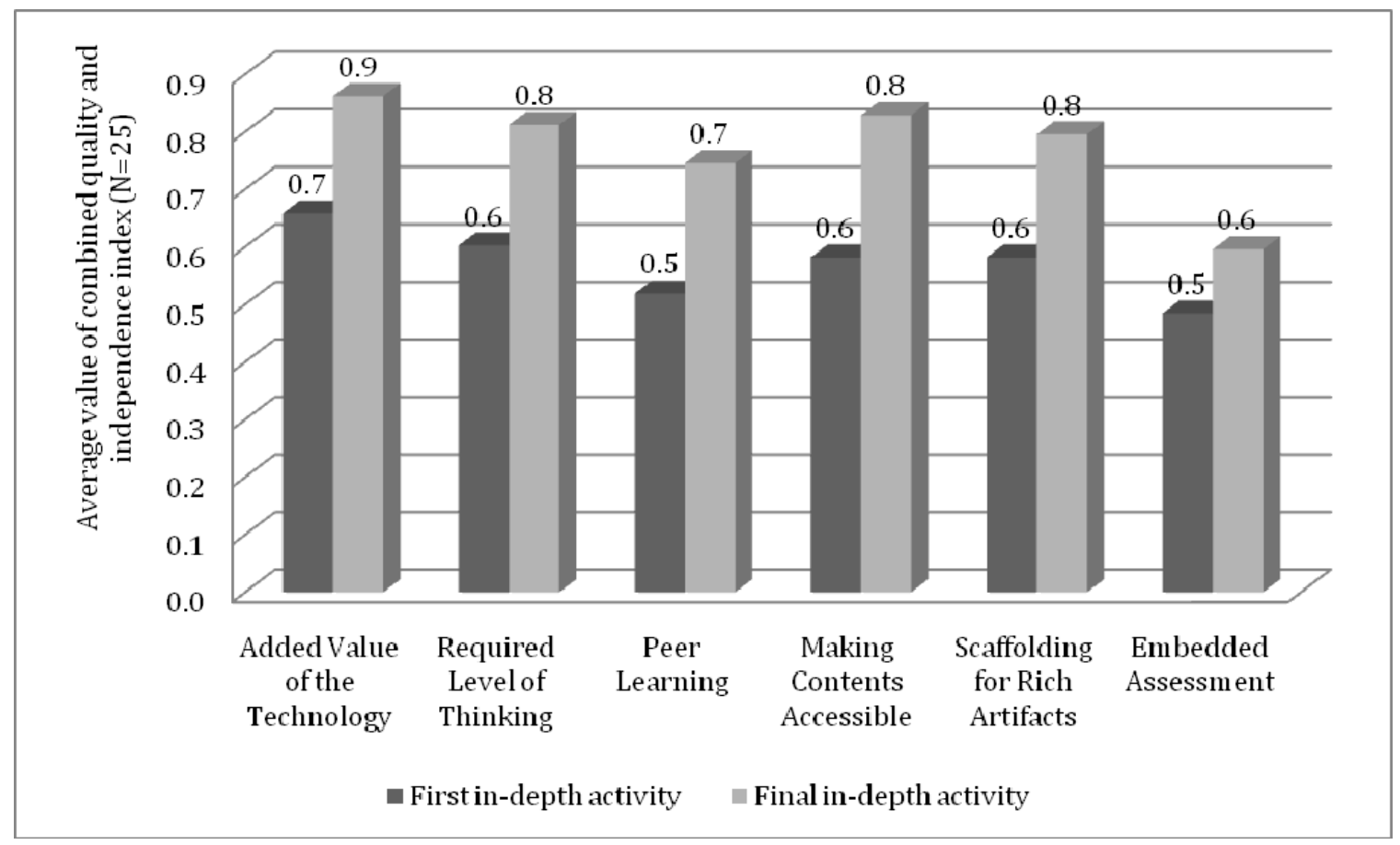

Figure 4: Comparison of average APA values for the first in-depth online activities
developed by the 25 teachers versus their final in-depth activities

Figure 4 shows that online activities developed by teachers toward the end of the intervention were significantly at a higher level than those developed at the beginning of the intervention. Significant differences were found in all the dimensions of the APA rubric. In other words, the TPD 
model enabled teachers to develop technological-pedagogical knowledge (TPK), in a socioconstructivist approach, which was reflected in the activities they developed.

This finding was also supported in teachers' reflective essays. Many of the teachers reported in those essays that the activities they develop today are at a much higher pedagogical level than those they developed at the beginning of the TPD program. Teachers reported that throughout the years they became more aware of the pedagogical rationales behind the activities they design. For instance one teacher says, "I looked back at activities I developed last year and was amazed to see how much my thinking has developed since then. Today I use the forum much more as a tool for students to share initial ideas, and build on each other ideas to develop their own thinking. I also know much better how to use materials that are out there on the Web to make the activities that I develop more powerful and more fun for the kids."

\section{Typical Teacher Profiles}

Four categories and nine sub-categories of teacher profiles emerged from the analysis of the qualitative data. Table 6 summarizes the patterns of practice and illustrates these patterns with example excerpts from teachers' sayings.

\section{Table 6: Typical teacher profiles}

\section{Profiles and number of teachers* \\ Leaders ( $\mathbf{N}=\mathbf{8}$ ) \\ - High frequency of activity development (about 1 in- depth activity per month) \\ - Quality of activities gradually became higher until reaching the highest levels.}

Independent ( $\mathbf{N}=7)$

- High frequency of activity development

- $\quad$ Diversity in type and quality of activities

\section{Patterns of Practice}

Natural Leaders ( $\mathbf{N}=4)$

Supported their colleagues from the beginning of the process. Became formal leaders.

Today my activities include more artifact-building... I usually have students provide feedback to each others' artifacts....

\section{Transformed Leaders $(\mathbf{N}=\mathbf{4})$}

Needed much assistance at beginning of process. Gradually became leaders.

As a new teacher I had a huge load in my first year... today I can't see myself teaching without online activities

\section{Adopters ( $\mathbf{N}=\mathbf{3})$}

Needed much assistance at beginning of process. Gradually became independent.

At the beginning of the process I hardly knew how to open the computer... Today this is another way for me to communicate with my students.

Isolated ( $\mathbf{N}=\mathbf{4})$

Overcame difficulties of working on their own.

It' difficult to invent activities on your own - It's a creative process which is much more fun to do with a colleague, but still, today I feel comfortable enough to do so. 


\begin{tabular}{l} 
Profiles and number of \\
teachers* \\
\hline Followers $(\mathbf{N}=\mathbf{2 1})$ \\
Intermediate level of activ- \\
ity development \\
Usually small activities and \\
intermediate level of qual- \\
ity.
\end{tabular}

at applicable ( $N=7$ )

- Low level of activity

\author{
Patterns of Practice \\ Steady $(\mathbf{N}=7)$ \\ Motivation to join came from wanting to take part in what has become \\ part of the school culture. Gradually became independent. \\ The kids were used to having their class website, I didn't have much \\ choice... \\ Social ( $\mathrm{N}=6$ ) \\ Had many difficulties with the technology, but stated active due to \\ working with partner. \\ If it wasn't for Galit I wouldn't have developed any of these activities, it's \\ good to commit to a regular hour in which we meet to work on our ac- \\ tivities. \\ Reluctant ( $\mathbf{N}=\mathbf{8})$ \\ I couldn't stay behind forever... Actually, this is easier than I thought it \\ would be.
}

\title{
Applied ( $\mathrm{N}=4$ )
}

These were usually teachers who taught subjects such as arts or sports and preferred that their students would engaged in doing art or sport, rather than in theoretical aspects of these topics. Their class-websites included links to relevant websites such as museums, or sport news sites.

Dropouts ( $\mathrm{N}=\mathbf{3}$ )

Dropped due personal or professional reasons. Professional reasons included other responsibilities in the school, or working with specific classes that would not benefit (according to the teachers) from a class website (such as first graders, or a special needs class)

* The total sum of teachers is 43 since we decided not to profile two teachers who dropped after the first year.

\section{Teacher-Turnover in the TPD Program}

Table 7 represents the number of teachers in each year, and a multi-year percentage of turnover in the intervention, as calculated using the Percentage of Teacher-Turnover formula described above. It is important to note that part of the turnover within the intervention was due to personnel changes in the schools, which were 33\% in school B and 7\% in school C (no personnel changes were in school A during the intervention).

As can be seen in Table 7, at the end of year three of the intervention, growing percentages of the teachers ( $86 \%$ in school A, $81 \%$ in school B, and 50\% in school C) became involved in the TPD and, thus, involved in creating and maintaining their class-websites. This included continuers, newcomers who were guided by leading teachers, and comebacks. The broadening of the percentage of technology adaptors in each of the schools, even though the mentor had faded away, signifies assimilation of the online technology into the culture of the schools. 
Table 7: Teacher participation and turnover in the intervention calculated using the Percentage of Teacher-Turnover formula.

\begin{tabular}{|c|c|c|c|}
\hline Intervention year & $\begin{array}{c}\text { School A } \\
22 \text { teachers in staff }\end{array}$ & $\begin{array}{c}\text { School B } \\
21 \text { teachers in staff }\end{array}$ & $\begin{array}{c}\text { School C } \\
12 \text { teachers in staff }\end{array}$ \\
\hline Year 1 & $\begin{array}{l}10 \text { participants } \\
\text { (45\% of staff) }\end{array}$ & $\begin{array}{l}1 \text { participants } \\
\text { (5\% of staff) }\end{array}$ & $\begin{array}{l}2 \text { participants } \\
\text { (17\% of staff) }\end{array}$ \\
\hline \multirow{2}{*}{ Year 2} & $\begin{array}{l}11 \text { participants } \\
\text { (50\% of staff) }\end{array}$ & $\begin{array}{l}13 \text { participants } \\
\text { ( } 62 \% \text { of staff) }\end{array}$ & $\begin{array}{l}7 \text { participants } \\
\text { ( } 58 \% \text { of staff) }\end{array}$ \\
\hline & $\begin{array}{l}\text { Continuers } 7 \\
\text { Dropouts } 3 \\
\text { Newcomers } 4\end{array}$ & $\begin{array}{c}\text { Continuers } 1 \\
\text { Dropouts } 0 \\
\text { Newcomers } 12\end{array}$ & $\begin{array}{l}\text { Continuers } 2 \\
\text { Dropouts } 0 \\
\text { Newcomers } 5\end{array}$ \\
\hline \multirow[b]{2}{*}{ Year 3} & $\begin{array}{l}19 \text { participants } \\
\text { (86\% of staff) }\end{array}$ & $\begin{array}{l}17 \text { participants } \\
\text { (81\% of staff) }\end{array}$ & $\begin{array}{l}6 \text { participants } \\
\text { (50\% of staff) }\end{array}$ \\
\hline & $\begin{array}{l}\text { Continuers } 11 \\
\text { Dropouts } 0 \\
\text { Newcomers } 6 \\
\text { Comebacks } 2\end{array}$ & $\begin{array}{l}\text { Continuers } 11 \\
\text { Dropouts } 2 \\
\text { Newcomers } 6\end{array}$ & $\begin{array}{l}\text { Continuers } 5 \\
\text { Dropouts } 2 \\
\text { Newcomers } 1\end{array}$ \\
\hline $\begin{array}{l}\text { Average Percent- } \\
\text { age of turnover in } \\
\text { three years of in- } \\
\text { tervention }\end{array}$ & $41 \%$ & $69 \%$ & $54 \%$ \\
\hline
\end{tabular}

\section{Frequency of Class-Website Updates}

Figure 5 represents the average frequency of updates, at a school level, for each of the three schools throughout the four years of the study (the three years of the intervention and one year after the study).

It can be seen that the activity in all three of the schools' websites significantly increased throughout the years of the intervention and for at least the year following. The increase in school C's online action was somewhat lower than in schools A and B. This can be explained due to the fact that it was a smaller school that had fewer teachers. As a result, teachers in this school had more responsibilities, and only about half of them joined the TPD program (see Table 7). As explained above, the portion of teachers who develop and maintain class-websites is an important factor in calculating the frequency of updates at a school level, which explains the lower frequency of updates in school C.

Figure 5 also shows that December through April are the peak months in online activity in each of the schools, and that the activity is slowed down a bit in May to June and in September to October. This can be explained by the high work-load on teachers at the beginning and ending of each school year.

The average frequency at a school level in the three years of the study, while the TPD program was running (as illustrated in Figure 5), shows that our goal to reach assimilation of technology into the schools' cultures, and into the teachers' everyday practices was reached. It is important to 


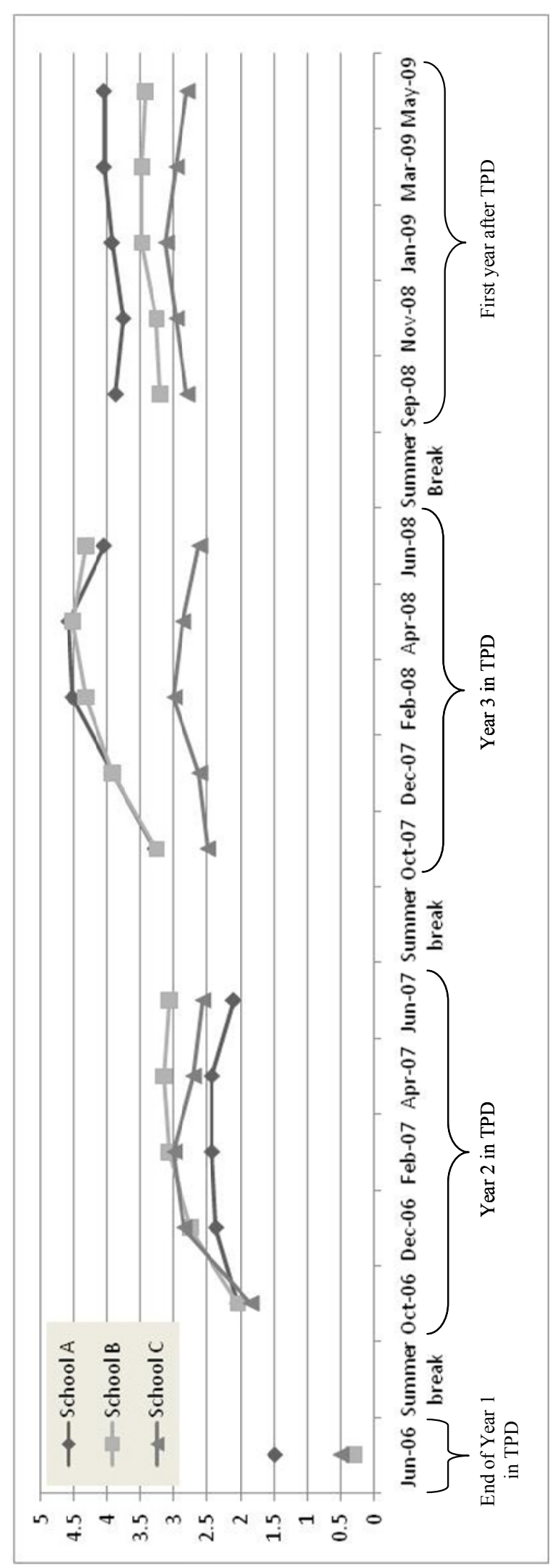

Figure 5: Average frequency of updates to schools' websites throughout the study note that this assimilation was reached inspite of the high teacher-turnover in the TPD program throughout the intervention (Table 7).

In addition to that, Figure 5 shows that the assimilation of technology was sustained one year after the project. As can be seen from the graph, there was a slight decrease in the online action from the third and final year of the intervention to the year that followed it, in which no intervention was made in the schools. However, the average frequency of updates to the class-websites stabilized at a high level. It is important to note that the percentage of turnover in the schools due to teachers' sabbaticals and incorporation of new teachers was high in all three schools in this year (between $13 \%$ to $25 \%$ ). In-spite of the high personnel changes, the schools maintained a stable and high level of online action. This was expressed in a high portion of teachers who continued (or started) to develop and use online activities: $81 \%$ of the teachers in school A, $85 \%$ of the teachers in school $\mathrm{B}$, and $50 \%$ of the teachers in school C (Table 7).

To examine our interpretation of the growth in teachers' updates of their classwebsites as an effect of the TPD model on assimilation of technology into the schools' culture, we examined the amount of action in class-websites in the fourth school, in which the TPD model was not implemented. The analysis showed that in this school, the average frequency of updates stayed lower than 1 even after three years of mentoring. In other words, without the addition of the TPD model, this school maintained the low rates that characterized the end of the first year in schools A, B, and C. The online action in this school never reached the high levels that characterized schools A, B, and C from the second year to the fourth year of the study. 


\section{Other Evidences for the Assimilation of Online Technologies into the Schools' Cultures}

In addition to teachers' frequency of updates to the class-websites, support of the findings regarding the assimilation of technology into the culture of the three schools and of the sustainability of this change was also found from the following evidence.

Analysis of the type of activities developed by teachers in the fourth year of the study shows that the high action and updating in the schools' websites (Figure 5) included a large portion of indepth activities developed (or refined) by the teachers.

Additionally, we found that many teachers in the third and fourth year of the study began to reuse in-depth activities that they had developed in earlier years, and they reported that this makes the implementation of online activities much easier and also enables them to improve the activities from year to year. For instance, one of the teachers said, "In the past two years I've built many activities - some were better than others. This year it's much easier for me. Most of my activities are an upgrade of earlier activities. I check the links, and enrich the activity with some new ones, I make some changes to make the activity fit a different context or audience, and I try to make it more interesting and creative for the students."

Finally, more evidence of technology assimilation into the schools' culture was found in teachers' sayings in a visit the mentor paid to each of the schools about half a year after the intervention was over. It was evident that all the frameworks that were established during the last year of the study to continue the process (see Table 2) were maintained. The teachers and principals were very satisfied and proud that they were able to keep the online action without the mentor and mentioned that new teachers joined the activity. The spirit of these meetings is evident from one of the leading teachers' words, "It's going very well; the principal is very much involved. Every week she and I enter the other teachers' class-websites and provide them with feedback. I have regular meetings with the new fifth-grade teacher - she's enthusiastic to join the game. Most of the other teachers are independent. Here and there I help them with technical issues like making links to images and stuff like that...".

\section{Discussion}

The attitude towards teacher training programs for computer literacy and use of technology in education during the 80 's and 90 's can be best described as "patronizing". External organizations - authorities, academia, commercial, or technology companies - exerted a lot of pressures on schools to "reform", and to reform fast. In his book "Oversold \& underused: Computers in the classroom," Larry Cuban (2001) criticizes this approach and claims that all these technologycentric reforms were short-lived, achieved sporadic and local changes, and failed to achieve the desired goal. In another book, "Tinkering toward Utopia: A century of public school reform," Tyack and Cuban (1997) show that the desire to reform schools and educational systems in short timeframes is utopian. They claim that all successful reforms in schools were implemented in an organized and gradual pace, taking local requirements into consideration, and were conducted with full cooperation with schools and teachers. They assert that:

Focusing only on change runs the danger of ignoring continuity in the basic practices of schools.... Change, we believe, is not synonymous with progress... Although policy talk about reform has had a utopian ring, actual reforms have typically been gradual and incremental... It may be fashionable to decry such change as piecemeal and inadequate, but over long periods of time such revisions of practice, adopted to local contexts, can substantially improve schools. (p. 4-5) 
The goal of the current research was to design and evaluate a TPD model teachers can use for assimilation of online technologies, in a socio-constructivist approach, into their school culture. Following Larry Cuban's ideas, the TPD model was designed to use and empower existing school resources. The available resources included all aspects of the school's human capital: The principals and teachers, their tacit knowledge and experience, their perceptions and educational beliefs, and the school culture and policies. Additional resources were the ICT and computers infrastructure and external funding from the Ministry of Education, which were part of the national effort to assimilate online technologies into schools.

In building the TPD model, we followed our philosophy and belief that the intervention model for teachers should follow the same instructional approaches that we thought teachers would implement with students. We also encouraged teachers to follow their personal and collective practical experience and tacit knowledge. The TPD was not designed to, and not intended to, replace teachers' instructional practices or replace old curriculum with new or better pedagogical materials. Quite the contrary - the TPD was designed to enhance existing pedagogical content knowledge of the teachers by providing new technological and pedagogical methods. Nonetheless, we claim that the schools that participated in the three-year intervention program demonstrated a sustained and significant reform. We base this claim both using the school-reform perspective and the technology adoption life-cycle perspective.

\section{Interpreting the Change Using the School Reform Perspective}

In order to evaluate the degree of the change that occurred in the three schools, its scope, magnitude and substantial assimilation, we used Fuchs' (1995) theoretical framework, as presented in her book "Change - A way of life in schools." By using this three-level categorization to interpret the research findings and to evaluate the level of assimilation of the change, our findings indicate that the schools reached the highest level of assimilation - change of a $3^{\text {rd }}$ degree - following the implementation of the three-year TPD model.

At beginning stages of the intervention the focus of the TPD was at a technical level; the teachers had to pass a certain level of comfort and experience with the software tools, before they were able to deal with pedagogical issues. This finding is consistent with Capper's (2003) earlier findings. It was only towards the end of the first year that teachers started, under substantial mentoring and guidance, to develop their first in-depth online activities. Our findings (Figure 4) show that the activities they designed at that stage represent conservative pedagogical approaches: the teacher was still in the center, there was limited or no reference to collaborative learning, no attempt to relate the contents to the student's knowledge and experience, and most activities engaged students in simple tasks that require very little creativity and low level of thinking. As a matter of fact, we decided to enact activities in which the school-staff brainstorms ideas about how to integrate online technologies in the school's vision only at the second year of the intervention, because we felt that only then school-staffs became mature enough for such activities. Only after teachers were aware of the affordances and constraints of the LCMS, and had enough experience in designing and enacting small online activities, were they able to gain a school-wide perspective and attitude for revisiting the schools' vision to incorporate technology. Thus, the TPD model includes the school's vision brainstorming activity in year 2 (see "training stage", Table 2), after successful conclusion of one year of training.

During the first year of the intervention, all three schools were already going through a change of the first degree, as defined by Fuchs (Table 1). At this point, the change existed at the level of action (usage of a class website); it was not yet a rationale-based change, and certainly not a change in the essence of the school's vision. The change in the first year of the intervention indicates a progress in an existing trajectory (conservative pedagogy) and not in the development or implementation of a new trajectory (socio-constructivist pedagogy). At this stage, schools were 
highly dependent on an external resource (the TPD mentor), the process attracted the interest of a small group (just a few of the teachers) while other groups opposed the change (many of these teachers were later characterized as "independent adopters" or "followers"), therefore the number of elements that were changed (subject matter areas in which technology was incorporated) was low.

Using the same theoretical framework to evaluate the change in years 2 and 3 of the intervention, we find that the change - both at the teacher level and at the school level - was significant and indicated a $3^{\text {rd }}$ degree change (the highest level of assimilation of change). The end-process reached a holistic, multi-dimensional change of all elements and a change in vision. The natural development of a strong, committed nucleus of change agents (the leading teachers profiled in Table 6) played a key role in the change process. Equally important was the active support by principals, as described by the activities during the coaching phase and the fading-away phase (Table 2). The relatively high rate of leading teachers allowed the TPD mentor to delegate responsibilities to the school at the end of the intervention program. Moreover, third-year activities of planning frameworks for sustained autonomous online activities at the teachers, school, and district levels supported the fading out of the TPD mentor (see "fading-away" activities, Table 2). The design of the fading-away activities was based on the role of ICT in school's vision, as defined by the teachers in the second year. A critical mass of teachers joined the process in the third year - teachers from all areas developed their class-websites and updated them on a regular basis (except for music, arts, gymnastics and computer teachers, who preferred to design informational sites and work with their students on practical aspects in these areas).

The teachers' profiles (Table 6) and their participation rate and turnover (Table 7) clearly show the buildup of a "school's spirit" and enthusiasm that calls teachers to engage in the process. Some teachers who initially ignored or opposed the project started to show a growing interest, joined the project, and some even transformed over time to become leaders and enroll others to the project (Table 6). Our findings show an impressive professional development at the teacher level; in the third year of the intervention, a majority of the teachers gained independence in designing online activities and demonstrated high personal motivation and high rate of class-website updates, resulting in the high average frequency of updates in schools' websites (Figure 5). The in-depth activities, the interview protocols, and the reflective assays indicate a substantial enhancement in the teachers' technological-pedagogical knowledge (TPK) and in their understanding of the added value of online technologies to promote socio-constructivistic approaches (Figure 4).

Thus, we view the level of change in the culture of the three schools and the assimilation of online technologies achieved, after the three-year intervention program and beyond, as a change of the highest level - change of the $3^{\text {rd }}$ degree in Fuchs' framework. The change is reflected not only in the doing (designing online activities and site updates) but also in the being - implementing online pedagogies that are in line with the school vision and thoughtful planning of novel educational activities. Schools archived full autonomy by the development of a strong nucleus of leading teachers, resulting in continuity and sustained high average frequency of updates of the class websites. The change involved all parties, and the vast majority of the teachers accepted the change. Clearly, the change was qualitative and holistic.

\section{Interpreting the Change Using the Technology Adoption Life Cycle Perspective}

The power and degree of the change can also be deduced using the technology adoption model. As described above, this model asserts that innovation is adopted by the majority when the adoption reaches the late-majority category of users. All three schools that participated in the TPD program demonstrated a penetration level into the late-majority category. This observation is in 
line with the school reform perspective and supports the claim that the schools reached the highest level of change and adoption of the technology.

We would like to note that the profiles found in the current study (Leaders, Independent, Followers, and TPS not applicable) do not match the categories described in the technology adoption life-cycle (Innovators, Early adopters, Early majority, Late majority, and Laggards). However, the patterns of practice that characterize the teacher profiles illustrate very nicely the processes that Roger (1995) and Moore (2002) described for technology adoption, from its acceptance by early majority to the stage in which the "product" evolves, becomes a "whole product" and is accepted by the late majority. It is important to note that the model was initially designed to reach the early majority of the teachers. Therefore the online technology was augmented with activities designed to assist the pragmatist (early majority) teachers to adopt it, since the technology and the support were brought to them, and they did not need to find ways to solve problems by themselves to make it work. Indeed, most of the teachers stayed in the TPD program after the first year (Table 7), which demonstrates that the activities designed for the first year of the TPD provided the required augmentation to match these pragmatists' expectations from the online technology. In this manner were able to bridge the first chasm described by Moore between early adopters and early majority.

The second chasm - the one between the early majority and the late majority - was more evident in our findings. The late majority, or the conservatives, adopt innovation only when it becomes mainstream. In terms of the "whole product" approach, this is when a product is perceived to provide the maximum of its objective, becomes standard, and has clear procedures, advanced training, and integration. The activities in the second year of the TPD bridged this gap by making the innovation an integral part of school's vision and enabling the change reform team to build procedures and methodologies for the use of online technologies. The interview protocols show this change in attitude, as reflected by the "steady" followers reasoning to adopt the change, "The kids were used to having their class website, I didn't have much choice...," and the "reluctant" followers, "I couldn't stay behind forever... Actually, this is easier than I thought it would be."

\section{Conclusion}

The discussion above shows that, in both the school reform perspective and the technology adoption life-cycle perspectives, the change process that schools went through was substantial. Our rationale that with the same resources, allocated by the ministry of education, a greater impact would be reached with a more holistic TPD approach than the individual guidance model was greatly supported by the findings of this research. The three-year TPD model was found as highly valuable in enabling schools to step up and achieve meaningful and sustainable assimilation of socio-constructivist online instruction. Using the cognitive apprenticeship framework (modeling, coaching, fading-away) the TPD program enabled teachers to gain skills and confidence in autonomously developing their own online activities while allowing the mentor to decrease the mentoring hours over time. The collaboration and teamwork among teachers created motivation, commitment, and responsibility. Experienced teachers assumed leadership roles and helped novice teachers, which, in return, enlarged the number of involved teachers. This collaboration enriched both the quantity and quality of online activities developed by teachers and streamlined the design of new activities and website updates. Moreover, the collaboration and teamwork influenced the hesitant and opposing teachers to change their attitude and to take part in the project. As the number of participating teachers increased, so did the enthusiasm and the school spirit towards the assimilation of the online technologies into the school culture. All these processes were supported by the TPD model; the school which received the same resources without the TPD model did not reach such high achievements. 
Our findings also show that teachers can play a key role, not only as partners in designing educational technologies as described in the literature (Fishman et al., 2004), but also as autonomous designers and developers of their own online activities. The uniqueness of our TPD model, with its three dimensions and twenty-seven cubes of activities, enabled teachers to successfully take this role.

Finally, the intervention approach of using and empowering local resources proved itself, not only in the effectiveness of change implementation, but also in generating a sustainable reform, in which activity continued to take place at a high level even one year after the intervention has finished.

However, a limitation of this research is that it studied the intervention only in elementary schools. In order to examine the generalization of this model to other types of institutions (such as high-schools and/or large corporations) further research is required. Additionally, further research is required to determine whether such an approach can support a more long-lasting effect.

\section{References}

Becker, H. J., \& Ravitz, J. (1999). The influence of computer and Internet use on teachers' pedagogical practices and perceptions. Journal of Research on Computing in Education, 31(4), 356-384.

Bloom, B. S. (1956). Taxonomy of educational objectives: The classification of educational goals. New York: McKay.

Bowyer, J., Gerard, L., \& Marx, R. (2008). Building leadership for scaling science curriculum reform. In Y. Kali, M. C. Linn \& J. E. Roseman (Eds.), Designing coherent science education: Implications for curriculum, instruction, and policy (pp. 123-152). N.Y.: Teachers College Press.

Capper, J. (2003). Complexities and challenges of integrating technology into the curriculum. TechKnowLogia, 5(1).

Chi, M. T. (1997). Quantifying qualitative analyses of verbal data: A practical guide. Journal of the Learning Sciences, 6(3), 271-315.

Collins, A., Brown, J. S., \& Newman, S. E. (1989). Cognitive apprenticeship: Teaching the craft of reading, writing, and mathematics. In L. B. Resnick (Ed.), Cognition and instruction: Issues and agendas (pp. 453-494). Hillsdale, NJ: Lawrence Erlbaum Associates.

Cordingley, P., Bell, M., Rundell, B., \& Evans, D. (2003). The impact of collaborative CPD on classroom teaching and learning. Journal. Retrieved from http://www.gtce.org.uk/shared/rotm/103260/collaborativecpdrom.pdf

Cuban, L. (1990). Reforming again, again, and again. Educational Researcher, 19(1), 3-13.

Cuban, L. (1993). Computers meet classroom: Classroom wins. Teachers College Record, 95(2), 185-210.

Cuban, L. (2001). Oversold \& underused: Computers in the classroom: Harvard university press Cambridge, Massachusetts London, England.

Davis, E. A., \& Varma, K. (2008). Supporting teachers in productive adaptation. In Y. Kali, M. C. Linn, M. Koppal \& J. E. Roseman (Eds.), Designing coherent science education: Implications for curriculum, instruction, and policy (pp. 94-122). N.Y.: Teachers College Press.

Dawes, L. (1999). First connections: Teachers and the national grid for learning. Computers \& Education, $33(4), 235-252$.

Dori, Y. J. (2003). From nationwide standardized testing to school-based alternative embedded assessment in Israel: Students' performance in the "Matriculation 2000" Project. Journal of Research in Science Teaching, 40(1), 34-52.

Dori, Y. J., Tal, T., \& Peled, Y. (2002). Characteristics of science teachers who incorporate web-based teaching. Research in Science Education, 32(511-547). 
Ellis, A., \& Phelps, R. (2000). Staff development for online delivery: A collaborative, team based action learning model. Australian Journal of Educational Technology, 16(1), 26-44.

Fishman, B., Marx, R., Blumenfeld, P., Krajcik, J. S., \& Soloway, E. (2004). Creating a framework for research on systemic technology innovations. Journal of the Learning Sciences, 13(1), 43-76.

Fuchs, I. (1995). Change - A way of life in schools. Tel-Aviv: Cherikover publishers (in Hebrew).

Fullan, M. (2006). The future of educational change: System thinkers in action. Journal of Educational Change, $7(3), 113-122$.

Fuller, D., Norby, R. F., Pearce, K., \& Strand, S. (2000). Internet teaching by style: Profiling the on-line professor. Educational Technology \& Society 3(2).

Furman-Shaharabani, Y., \& Tal, T. (2008). Long-term professional development of science teachers: Conceptual and practical aspects. Paper presented at the EARLI, Special Interest Group: Teaching and Teacher Education, Switzerland.

Green, W. D., \& O'Brien, T. (2001). The internet's impact on teacher practice and classroom culture. T.H.E Journal Online.

Guskey, T. R. (1998). Teacher efficacy, self-concept and attitudes towards the implementation of instructional innovation. Teaching and Teacher Education : An International Journal of Research and Studies, 4, 63-69.

Hargreaves, A., \& Fullan, M. (1992). Introduction- Understanding teacher development. NY: Teachers College Press.

Harris, J. (1994). Mining the internet: Teaching teachers to use telecomputing tools. The Computing Teacher, 21(6).

Herrington, J. A., Reeves, T. C., \& Oliver, R. (2005). Online learning as information delivery: Digital myopia. Journal of Interactive Learning Research 16(4), 353-367.

Janson, A., \& Janson, R. (2009). Integrating Digital Learning Objects in the Classroom: A Need for Educational Leadership. In Innovate, Journal of Online Education, 5(3).

Kali, Y., Levin-Peled, R., \& Dori, Y. J. (2009). The role of design-principles in designing courses that promote collaborative learning in higher-education. Computers in Human Behavior, (Available online at http://dx.doi.org/10.1016/j.chb.2009.1001.1006).

Kali, Y., \& Linn, M. C. (2007). Technology-enhanced support strategies for inquiry learning. In J. M. Spector, M. D. Merrill, J. J. G. V. Merriënboer \& M. P. Driscoll (Eds.), Handbook of research on educational communications and technology (3rd Edition) (pp. 445-490). Mahwah, NJ: Erlbaum.

Kearsley, G., \& Blomeyer, R. (2004). Preparing K-12 teachers to teach online. Educational Technology: The Magazine for Managers of Change in Education, 1, 49-52.

King, K. P., \& Dunham, M. D. (2005). Finding our way: Better understanding the needs and motivations of teachers in online learning. Journal for Instructional Technology and Distance Learning, 2(5).

Koszalka, A. T. (2001). Effect of computer-mediated communications on teachers' attitudes toward using web resources in the classroom. Journal of Instructional Psychology, 28(2), 95-103.

Kumari, S. (1998). Teaching with the Internet. Journal of International Technology and Teacher and Education, 7(3), 363-377.

Linn, M. C., Davis, E. A., \& Bell, P. (Eds.). (2004). Internet environments for science education. Mahwah, NJ: Lawrence Erlbaum Associates.

Mioduser, D., \& Nachmias, R. (2002). WWW in Education: An Overview. In H. Adelsberger, B. Collis \& M. Pawlowsky (Eds.), Handbook on Information Technologies for Education \& Training (pp. 23-43). Berlin/Heidelberg/New York: Springer. 
Mishra, P., \& Koehler, M. J. (2006). Technological pedagogical content knowledge: A framework for teacher knowledge. Teachers College Record, 108(6), 1017-1054.

Moore, G. A. (2002). Crossing the chasm: Marketing and selling disruptive products to mainstream customers. New York: HarperBusiness.

Peled, Y., Kali, Y., \& Dori, Y. J. (2007). Interaction between science teachers and school principals and its influence on technology implementation: A retrospective analysis. In Y. Eshet, Caspi, A., \& Yair, Y. (Ed.), Proceedings of the 2nd Chais conference: Instructional technologies research, learning in the technological era, 2007 (pp. 117-121). Ranana: The Open University.

Piaget, J. (1972). Science of education and the psychology of the child. New York: The Viking Press.

Ravitz, J. (1998). Conditions that facilitate teachers' Internet use in schools with high Internet connectivity: Preliminary Findings. Retrieved from http://www.bie.org/Ravitz/Ravitz_AECT98.html

Robbins, S. R. (2002). The evolution of the learning content management system: Learning circuits, ASTD's source for E-Learning. Retrieved from http://www.learningcircuits.org/2002/apr2002/robbins.html

Reeves, T. C., \& Reeves, P. M.. (1997). The effective dimensions of interactive learning on the WWW. In B. H. Khan (Ed.), Web-based instruction (pp. 59-66). New Jersey: Educational Technology.

Rogers, E. M. (1995). Diffusion of innovations. New York: Free Press.

Roschelle, J., Pea, R., Hoadley, C., Gordin, D., \& Means, B. (2000). Changing how and what children learn in school with collaborative cognitive technologies. The Future of Children, 10(2), 76-101.

Ryann, K. E. (2001). LCMS Roundup. Retrieved from http://www.learningcircuits.org/2001/aug2001/ttools.htm

Salomon, G. (2000). It's not just the tool, but the educational rationale that counts. Keynote paper presented at the 2000 Ed-Media Meeting.http://www.aace.org/conf/edmedia/00/salomonkeynote.htm

Salomon, G., \& Ben-Zvi, D. (2006). The difficult marriage between education and technology: Is the marriage doomed? In F. D. L. Verschaffel, M. Boekaerts and S. Vosniadou (Ed.), Instructional psychology: Past, present and future trends: Essays in honor of Erik De Corte (pp. 209-222): Elsevier.

Shamir-Inbal, T., \& Kali, Y. (2007). The relation between schoolteachers' perceptions about collaborative learning and their employment of online instruction. In C. A. Chinn, G. Erkens \& S. Puntambekar (Eds.), Proceedings of the Computer Supported Collaborative Learning (CSCL) 2007: Mice, Minds and Society (pp. 292-300): International Society of the Learning Sciences, Inc.

Shamir-Inbal, T., \& Kali, Y. (2009a). Teachers as curriculum designers: The effect of a teacher professional development program. Paper presented at the annual meeting of the American Educational Research Association (AERA), San Diego, CA.

Shamir-Inbal, T., \& Kali, Y. (2009b). Teachers as designers of online activities: The role of socioconstructivist pedagogies in sustaining implementation. Design Principles \& Practices: An International Journal.

Shulman, L. S. (1986). Those who understand: Knowledge growth in teaching. Educational Researcher, $15(2), 4-14$.

Tyack, D., \& Cuban, L. (1997). Tinkering Toward Utopia: A Century of Public School Reform. Cambridge, MA: Harvard University Press.

Varma, K., Husic, F., \& Linn, M. C. (2008). Targeted support for using technology-enhanced science inquiry modules. Journal of Science Education and Technology.

Vygotsky, L. S. (1978). Mind in society: The development of higher psychological processes. Cambridge, MA: Harvard University Press.

Young, M.F. (1993). Instructional design for situated learning. Educational Technology Research and Development, 41(1), 43-58. 


\section{Biographies}

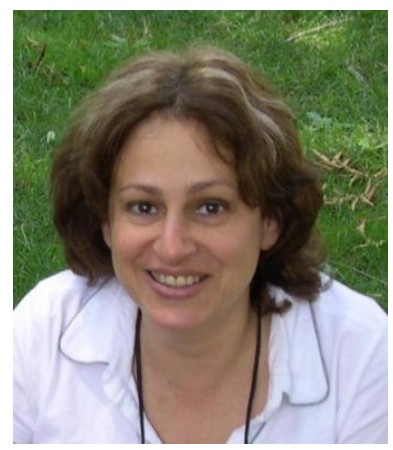

Dr. Tamar Shamir-Inbal received her Ph.D at the department of Education in Technology and Science at the Technion in Israel. Her research focuses on long term teacher professional development intended for encouraging teachers to adopt technology-enhanced strategies for their everyday instruction and for developing and implementing socio-constructivist pedagogies in online activities. Tamar received her M.Ed. Cum Laude from Tel Aviv University and has been working for many years as an instructor in various teacher professional development programs aimed at integrating technology into schools .

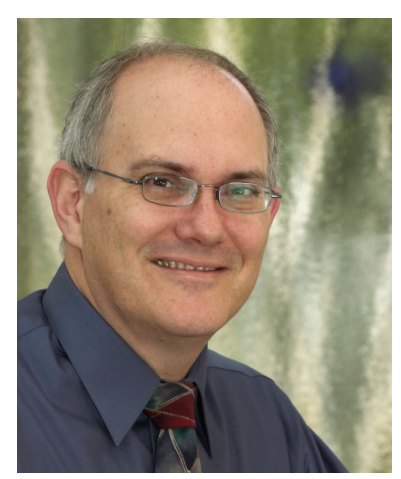

Jacob Dayan is a graduate student at the Education in Science and Technology Department at the Technion in Israel. Jacob holds a B.Sc. In Electronics Engineering from the Technion (1982), and has over 20 years of experience in international sales and business development. Jacob is the founder of SalesMind (2001), a private consulting firm that provides CEO consulting and business development services to Israeli high-tech startups. In addition, Jacob volunteers for the past 7 years as a Scoutmaster at the Israeli Scouts Association, responsible for a club of 350 scouts in his hometown. His research focuses on use of Multi-User Virtual Environment (MUVE) games for the learning of science in afterschool settings.

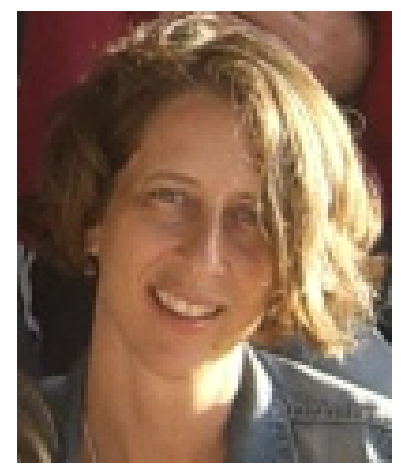

Yael Kali is an Associate Professor at the Education in Science and Technology Department at the Technion in Israel. The group she leads at the Technion focuses on design-principles for educational technologies and studies how technology enhanced learning environments affect learning at various levels (middle-school, high-school, highereducation and teachers). She is currently a visiting scholar at the centre for Research on Computer Supported Learning and Cognition (CoCo). She was a co-principle investigator in the NSF-funded Technology Enhanced Learning in Science (TELS) center, in which she developed the Design Principles Database and studied its contribution to the Learning Sciences and Design communities. She is the first editor of the book Designing Coherent Science Education: Implications for Curriculum, Instruction and Policy. She received her PhD from the Weizmann Institute of Science, Rehovot, specializing in earth science education. 